\title{
ACCURACY TEST OF SUPERMARKET'S MUSHOLA QIBLA DIRECTION IN CIREBON CITY
}

\author{
Samsudin ${ }^{1}$, Kusdiyana ${ }^{2}$, Rizal Ramadhan ${ }^{3}$ \\ 1,2,3 Faculty of Sharia and Islamic Economics IAIN Syekh Nurjati Cirebon \\ JI. Perjuangan ByPass Sunyaragi Cirebon, Jawa Barat 45132 \\ Email: ${ }^{1}$ samsudincrb28@gmail.com, ${ }^{2}$ kusdiyanacirebon@gmail.com, ${ }^{3}$ rizalramadhan294@gmail.com
}

\begin{abstract}
This study aims to answer the questions that become the formulation of the problem "How is the method of measuring the Qibla direction of the supermarket prayer room in Cirebon City" and "How to analyze the accuracy of the supermarket prayer room Qibla direction in Cirebon City." This study uses qualitative research; the data collected uses observation, interviews, documentation, and literature study. They were then analyzed by the descriptive analysis method in narration. The results of this study: that the Qibla direction of the supermarket in Cirebon City has all measured the Qibla direction. The method of measuring the Qibla direction was carried out by the musala supermarket, where the author's research uses the Qibla compass and the Qibla direction application on the smartphone. Of course, using the Qibla direction application on a smartphone is an inaccurate method. This method's method is partly an error in determining the Qibla direction. Due to his ignorance of astronomy in measuring the Qibla direction and ignorance of the magnitude of the Qibla direction angle in the Cirebon City area, resulting in the Qibla direction of the supermarket in the Cirebon City area experiencing a wrong Qibla direction.
\end{abstract}

Keywords: Qibla Direction Accuracy Test; Astronomy; Supermarket Musala

\begin{abstract}
Abstrak: Penelitian ini bertujuan untuk menjawab pertanyaan-pertanyaan tentang bagaimana metode pengukuran arah kiblat musala supermarket di Kota Cirebon?, dan bagaimana analisa terhadap keakurasian arah kiblat musala supermarket di Kota Cirebon?. Penelitian ini menggunakan penelitian kualitatif, data yang dikumpulkan adalah dengan cara observasi, wawancara, dokumentasi, dan studi kepustakaan. Kemudian dianalisis dengan metode deskriptif analisis dalam bentuk narasi. Adapun hasil penelitian ini: bahwa arah kiblat musala supermarket di Kota Cirebon semuanya sudah melakukan pengukuran arah kiblat. Adapun metode pengukuran arah kiblat yang dilakukan oleh musala supermarket tempat penelitian peneliti yaitu menggunakan kompas kiblat dan menggunakan aplikasi arah kiblat di smartphone. Tentu saja, metode menggunakan aplikasi arah kiblat di smartphone merupakan metode yang tidak akurat dan cara yang digunakan pada metode ini merupakan sebagian kesalahan dalam penentuan arah kiblat. Disebabkan ketidaktahuannya mengenai ilmu falak dalam mengukur arah kiblat dan ketidaktahuan besarnya sudut arah kiblat di wilayah Kota Cirebon, mengakibatkan arah kiblat musala supermarket di wilayah Kota Cirebon mengalami arah kiblat yang kurang tepat.
\end{abstract}

Kata kunci: Uji Akurasi Arah Kiblat; Ilmu Falak; Musala Supermarket 


\section{Introduction}

Terminologically, Qibla comes from the Arabic word "qiblah," a masdar form of qabbala, yuqabbilu, Qiblah, which means facing. According to the Indonesian Dictionary (KBBI), Qibla means the direction to the Kaaba in Mecca (when praying). Likewise, in the Qur'an, the word Qibla implies direction. It is found in QS al-Baqarah (2): 142-145 and means place. It is located in QS Yunus (10): 87.

Meanwhile, Slamet Hambali in Muhammad Hadi Bashori interprets Qibla as the direction to the Ka'bah (Mecca) through the closest route that every Muslim must face when praying. Meanwhile, according to Harun Nasution in Muhammad Hadi Bashori, Qibla is the direction to face at prayer times. From this definition, it can be concluded that the Qibla is the closest direction from the point to the Ka'bah, and every Muslim is obliged to face the Qiblah when praying. As for the most comparable order, because the earth is like a ball, there are only two paths: facing and turning back to the Kaaba. Therefore the most relative distance is the direction facing the Qibla. ${ }^{1}$

Astrology is a science that discusses the determination of the Qibla direction and can be solved by using the geometry of a spherical triangle. So that in determining the Qibla direction of the mosque, it will be proven by facing towards the Masjidil Haram. Therefore, Allah has prescribed that people who pray must turn their faces (faces) towards the Masjidil Haram (Kaaba) through His word. Among the words of Allah in the letter AlBaqarah/2: 144 as follows:

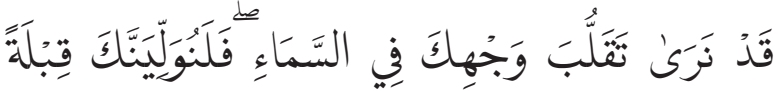

${ }^{1}$ Nurul Arifin, Integrasi Teks-Teks Syar'iYang Terkait Dengan Arah Kiblat Dalam Konteks Astronomi (Jurnal ElFalaky, Vol 4 No 1, 2020), p. 75.

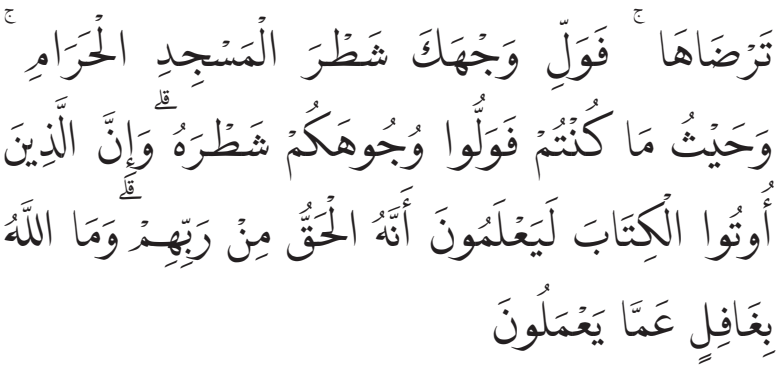

Meaning: "Indeed We see the turning of your face to heaven, so We shall surely turn you to a qiblah which you shall like; turn then your face towards the Sacred Mosque, and wherever you are, turn your face towards it, and those who have been given the Book most surely know that it is the truth from their Lord; and Allah is not at all heedless of what they do."

From the verse above, Allah determined to face the Grand Mosque as expected by the Prophet. The obligation to meet the Masjidil Haram applies in all places to perform prayers. This means that wherever we are, to perform prayers, we are required to complete the Qibla where the Qibla direction in Masjidil Haram. There is no problem for people close to Haram, but for people far from Mecca, it always causes problems and sometimes becomes a conflict among the people.

Related to this, some argue that it is obligatory to face the jihad only, ${ }^{3}$ although that, in essence, it is far from the actual direction. However, some say we must try to meet the maximum towards the precise focus. ${ }^{4}$ Therefore the Qibla direction is significant in carrying out prayers in the mosque and home. In general, Indonesian Muslims think that if you are facing the Qibla, you are facing west

\footnotetext{
${ }^{2}$ Departemen Agama RI., AL-Quran dan Terjemahnya (Jakarta: Proyek pengadaan Kitab Suci AL-Qur'an,1979), p. 37.

3 Abd. Karim Faiz, Moderasi fiqh Penentuan Arah Kiblat: Akurasi yang Fleksibel (JIL: Journal of Islamic Law,Vol 1, No 1, 2020), p. 84.

4 Badan Hisab dan Rukyat Departemen Agama, Almanak Hisab Rukyat (Jakarta: Proyek Pembinaan Badan Peradilan Agam Islam,1981), p. 17.
} 
according to the direction the sun is setting, ${ }^{5}$ while the sun's position rises and sets every day changing. If viewed from a macro scale, Indonesia is east of Mecca (Kaaba), so as a country east of the Kaaba, it should face west. However, determining the size of the degree of slope remains the main thing. The rise of discussion about the shifting Qibla direction at this time has also made Muslims worried whether the order of the Qibla they are going is correct or not.

Regarding this, the hadith of the Prophet guides by explaining the question of the direction of the Qibla, which Muslims must address in carrying out prayers in various places around the world. As in a hadith follows:

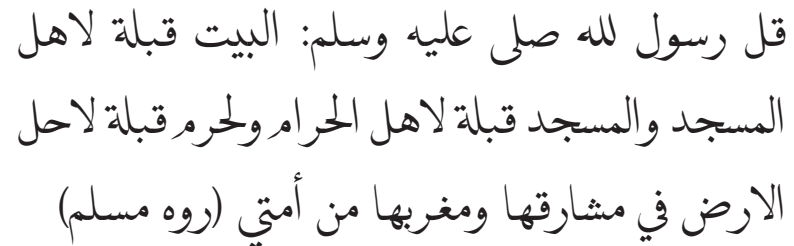

Meaning: "Baitullah is a mecca forpeople who pray in the Grand Mosque. While the Masjidil Haram is a mecca for residents of the city of Mecca. And the city of Mecca is a mecca for the inhabitants of the eastern hemisphere and the western hemisphere of my Ummah (H.R.Muslim)". ${ }^{6}$

The hadith above explains that areas far outside the city of Mecca that cannot be reached by eye are not required to be directed towards the Kaaba but are directed to the city of Mecca. In this case, the teachings of Islam itself need its adherents to keep trying to find the most correct and appropriate way that can be accounted for and then practice it to get the perfection of worship. Humans are always commanded to try so that the direction used precisely faces the Qibla (Baitullah). Besides

5 Yusuf somawinata, Penentuan Arah Kiblat dan Toleransi Penyimpangannya, (Jurnal Al-Ahkam, Vol 3, No 2, 2009), p. 84.

${ }^{6}$ Al-kurthuby, Al-Jami’u Lil Abkamil Qur'an juz II, p. 159. being very urgent in the validity of prayers, the order of the Qibla is also essential in the burial of the body, ${ }^{7}$ so this qibla issue needs necessary attention.

The mosque, a permanent building, allows Muslims to perform their prayers. It requires careful calculations in determining the direction of Qibla. Mistakes in deciding the direction of Qibla in mosques mean that indirectly as long as the mosque itself is still standing and used for prayer, it has directed people to pray in a direction other than the Qibla. Even because of the urgency, many academics and practitioners of Islamic law and astronomy are calibrating the Qibla direction in public spaces such as hospitals, airports, ${ }^{8}$ restaurants ${ }^{9}$, and malls.

Based on the development that determining the direction of the Qibla is very important but ironically in society sometimes underestimate it, in this case, it must be noted where the determination of the Qibla direction in the supermarket is only from the rest of the building space and only uses makeshift equipment and without being balanced with supporting scientific theory. Therefore, they are sometimes wrong in determining the direction of the Qibla, including in supermarkets in Cirebon City, people often talk about the order of Qibla.

According to the background above, the prayer room in this supermarket is beneficial, especially when people are shopping, then it is time for prayer and far to go to the mosque.

7 Hosen \& Eka Nurhalisa, Akurasi Arah Kiblat Pemakaman Desa Ponteh Kecamatan Galis Kabupaten Sumenep, (Jurnal Al-Marshad: Jurnal Astronomi Islam dan Ilmu-Ilmu Berkaitan, Vol 5, No 2, 2019), p. 149.

8 Anisah Budiwati \& Saiful Aziz, Akurasi Arah kiblat Masjid Di Ruang Publik (Jurnal Sains Sosial dan Humaniora, Vol 2 No 1, maret 2018), p. 159.

9 Hendri \& Zul Efendi, Problematika Ilmu Falak Kontemporer: Studi Kiblat Di Rumah Makan Pinggir Jalan Lintas Kabupaten/Kota Se Sumatera Barat (Jurnal Al-Marshad: Jurnal Astronomi Islam dan Ilmu-Ilmu Berkaitan, Vol 7, No 1, Juni 2021), p. 1. 
Muslims can use the facilities to worship, but it would be better if the accuracy of the Qibla direction had been tested with the correct method and calculation. The formulation of the problem in this research is:

a. What is the method of measuring the Qibla direction of the supermarket in Cirebon City?

b. How is the analysis of the accuracy of the Qibla direction of the prayer room supermarket in Cirebon City?

Meanwhile, the objectives to be achieved by researchers in conducting research are:

a. To find out what method is used by the manager of the prayer room in determining the Qibla direction of the supermarket prayer room in Cirebon City.

b. To determine the accuracy of the Qibla direction of the supermarket prayer room in Cirebon City.

\section{Qibla Direction in Fiqh Perspectives}

The scholars agree that people who can see the Ka'bah must face the building of the Ka'bah ('ain al-ka'bah) with full confidence. Meanwhile, for those who cannot see the Kaaba, the scholars have different opinions. First, most scholars other than Syafi'iyah believe enough to face the Ka'bah (jihah alka'bah) direction. The arguments put forward by Jumhur are the words of the Prophet narrated by Imam Ibn Majah and al-Tirmidhi as follows: ${ }^{10}$

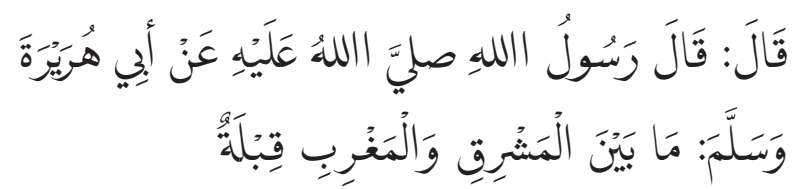

Meaning: "It was narrated from Abu Hurairah that the Messenger of Allah (SAW) said, "What being between East and West is Qibla."

10 Imam at-Tirmidzi, Sunan at-Tirmidzi, Juz I, (Beirut: dar al-Fikr, 2003)
This hadith means that all directions between North and South include the Qibla direction. ${ }^{11}$ Because if you are required to face the physical building of the Kaaba, then it is invalid for people who are in very long rows far from the Kaaba because they cannot ensure that their prayers are facing the physical building of the Kaaba. Whereas the Muslims agree that the prayers of these people are valid because what is required for those who cannot see the Kaaba building is facing the Kaaba. ${ }^{12}$

Second, Shafi'i argues that it is obligatory for those far from Mecca to face 'ain al$k a ' b a h$. According to Imam Shafi'i, people who require meeting the Qibla also need to meet oblige to face the Kaaba building like residents in Mecca. ${ }^{13}$ This is based on surah al-Baqarah/2 verse 150 :

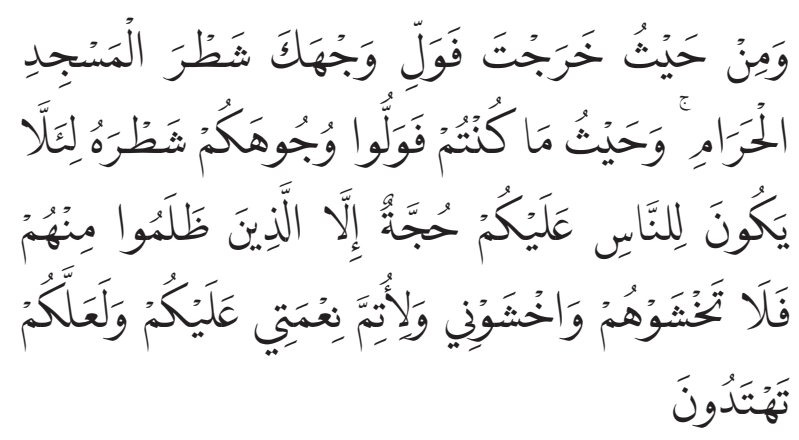

Meaning: "And from whatsoever place you come forth, turn your face towards the Sacred Mosque; and wherever you turn your faces towards it, so that people shall have no accusation against you, except such of them as are unjust; so do not fear them, and fear Me, that I may complete My favor on you and that you may walk on the right course." "l4

${ }^{11}$ Muhammad Yunus, Hadis Tentang Arah Kiblat: Kritik Pemikiran Ali Mustofa Yaqub (Jurnal Al-Irfani STAI Darul Kamal NW Kembang kerang Volume VI No 1 Tahun 2020), p. 11

12 Wahbah Zuhaili, al-Fiqh al-Islami wa Adillatuh, Jilid I, (Damaskus: Dar al-Fikr, 1997), p. 758

${ }^{13}$ Syaiful Mujab, Kiblat Dalam Persfektif MadzhabMadzhab Fiqh (Jurnal Yudisia, Vol 5, No 2, 2014), 331

14 https://quran.kemenag.go.id/sura/2/150, accessed on 3 November 2020 at 14.57 
The verse obliges us to face the Kaaba, which means we must face the physical Kaaba as people who can see the Kaaba directly. If the opinion of Syafi'iyah is followed, then the people will have difficulty carrying out the prayer, which is the mother of all worship in Islam (ummul 'worship) because people will have problems ensuring the accuracy of the Qibla direction due to various limitations, especially knowledge.

Meanwhile, according to Hanafiyah and Hanabilah, people who know the wrong direction of Qibla in their prayers do not need to cancel their prayers. It is enough for him to correct the order of the Qibla by turning his body towards the Qiblah, which is believed to be accurate, and continuing his prayer until it is finished. Likewise, for people who know the wrong direction of the Qiblah after finishing the prayer. He does not need to repeat his prayers. Because that person is in the same position as a mujtahid who makes ijtihad in determining the direction of Qibla. ${ }^{15}$ In particular, the theoretical framework used to analyze the data from the field is the theory of fiqh facing the Qibla direction and the formula for finding the Qibla direction.

The Qibla direction formula is as follows:

$\operatorname{Cotan} \mathbf{B}=\operatorname{Tan} \varphi m \mathbf{X} \operatorname{Cos} \varphi t: \operatorname{Sin} C-\operatorname{Sin}$ $\varphi t:$ Tan $C$

\section{Description:}

$\varphi \mathrm{m}$ : Makkah Latitude

$\lambda \mathrm{t}:$ Makkah longitude

$\varphi \mathrm{t}$ : Place Latitude

$\lambda \mathrm{t}$ : Place longitude

C : Longitude Distance

15 Yusuf Somawinata, Penentuan Arah Kiblat dan Toleransi Penyimpangannya, (Jurnal Al-Ahkam, Vol 3, No 2, 2009), p. 97
Meanwhile, to find the value of $\mathrm{C}$, the following conditions apply:

1. BTt $>$ BTm; $\mathrm{C}=\mathrm{BTt}-\mathrm{BTm}$ (Qibla direction leans west)

2. $\mathrm{BTt}<\mathrm{BTm}$; $\mathrm{C}=\mathrm{BTm}-\mathrm{BTt}$ (Qibla direction leans east)

3. $\mathrm{BBt}<\mathrm{BB} 140^{\circ} 10^{\prime} 20^{\prime \prime} ; \mathrm{C}=\mathrm{BBt}+\mathrm{BTm}$ (Qibla direction leans east)

4. BBt> BB $140^{\circ} 10^{\prime} 20^{\prime \prime} ; \mathrm{C}=360^{\circ}-\mathrm{BBt}-\mathrm{BTm}$ (Qibla direction leans west)

If the calculation result is positive $(+)$, the Qibla direction is calculated from the North point. However, if the calculation result is negative (-), the Qibla direction is calculated from the South. Meanwhile, to find out the coordinates of each mosque, the researchers used the Google Earth software.

After knowing the Qibla direction, then adjust the Qibla azimuth value. The provisions for calculating the Qibla azimuth are as follows:

If B (Qibla direction) is UT (+), Qibla azimuth will B (constant)

If B (Qibla direction) is ST (-), Qibla azimuth will $180^{\circ}+\mathrm{B}$

If B (Qibla direction) is SB (-), Qibla azimuth will $180^{\circ}-\mathrm{B}$

If B (Qibla direction) is UB (+), Qibla azimuth will $360^{\circ}-\mathrm{B}^{16}$

\section{Research methodology}

\section{Research Object}

In the object of this research, the researcher took the location according to the title of the research thesis above, namely the musala musala supermarket in Cirebon City.

16 Kementerian Agama.Buku Saku Hisab Rukayt. (Jakarta: Sub Direktorat Pembinaan Syariah dan Hisab Rukyat, 2013), p. 31-32 


\section{Research Approach}

The approach in this study uses a qualitative method in qualitative research using inductive reasoning methods and firmly believes that there are many perspectives to be expressed.

\section{Types of research}

This research uses the type of empirical research. That is a method that serves to see the law realistically and examine how the law works in the community. In this case, the author examines the accuracy of the Qibla direction of the supermarket prayer rooms and what methods and tools have been used previously in making measurements.

\section{Data source}

According to the Big Indonesian Online Dictionary, data is information or natural material that can be used as the basis for a study (analysis or conclusion). In this study, two types of data sources will be used, namely as follows:

a. Primary Data is data obtained directly from the first source. Data was obtained by conducting field studies (observation) or structured interviews guided by the list of questions that had been prepared. The primary data in this study is the initial data on the Qibla direction of the supermarkets and what methods and tools have been used previously in making measurements. The information was obtained directly from interviews with the managers of the supermarket prayer room.

b. Secondary data is data obtained by conducting a series of literature studies, namely carrying out a series of reading activities, citing, taking notes, studying astronomy books related to research problems. In this case, the researchers studied a lot from the pocketbook of reckoning rukyat of the Ministry of Religion of the Republic of Indonesia, the guidebook for determining the Qibla direction of the Ministry of Religion of the Republic of Indonesia, and other books related to the Qibla direction by figures and academics of astronomy as well as scientific journals related to research.

\section{Method of collecting data}

This qualitative research will use several types of data collection methods, namely as follows:

\section{a. Observations}

Observation is a systematic observation and recording of the phenomena studied. Based on the implementation and objectives of this research will use the Systematic Observation Method, namely the statement that has been previously determined the framework. Systematic observation is often assisted by employing recording mechanisms such as cameras, photographs, and recorders. In this case, the researcher records the data available at the location and conducts interviews with the local prayer room manager, and recalibrates according to the ideal data that the researcher calculates based on astronomy science.

\section{b. Interviews}

The interview is a question and answer process of two or more people directly about information or information. In this study, researchers conducted interviews with managers of supermarket prayer rooms in Cirebon, which became the object of research.

\section{Data Analysis}

After all the data has been collected, the next step is to analyze the data according to 
the focus of the research problem. The data analysis process carried out by researchers is as follows: research data analysis that adopts a qualitative approach is generally inductive or a combination of both. Inductive is the process of concluding minor case investigations in detail to get the big picture. In other words, the data in the form of fragments are assembled to produce a big shot that becomes the conclusion. Data analysis techniques according to are as follows:

\section{a. Data Reduction}

The data obtained by researchers from supermarket prayer rooms is quite a lot, for that it is necessary to record carefully and in detail. Reducing data means summarizing, choosing the main things, focusing on the essential things, looking for themes and patterns, and removing unnecessary ones. Thus the decreasing data will provide a clearer picture in this study and make it easier for researchers to conduct further data collection related to the Qibla direction accuracy test in the musala supermarkets in Cirebon city.

\section{b. Data Appearance}

After the data is reduced, the next step is to display the data. In research with a qualitative approach, data presentation can be done in brief descriptions, charts, relationships between categories. In this case, the author displays data in the form of short illustrations, diagrams, relationships between types, and so on related to the initial data on the existing supermarket musala Qibla direction and then synchronized with the author's ideal information calculates based on astronomy science.

\section{c. Conclusion and Verification}

In this study, the conclusions raised from the results of the calibration of the Qibla direction of the supermarkets are supported by valid and consistent evidence when researchers return to the field to collect data, so the conclusions put forward are credible. ${ }^{17}$

\section{Discussion}

They got mixed results on the Qibla direction of the prayer room for each supermarket when doing the research. The researchers will list the methods used by the supermarket prayer room manager to determine the direction of the supermarket prayer room qibla in the Cirebon City area. This is necessary to standardize the analysis of the method used to determine the direction of the prayer room. The method/ equipment used by the supermarket musola manager to determine the direction of the Qibla is using the Qibla direction application found on the smartphone.

Based on the method widely used by managers of supermarket prayer rooms in Cirebon City, all these supermarket prayer rooms use the measurement of the Qibla direction based on smartphone applications. Therefore, the method he uses does not meet the standardized measure of the Qibla direction in astronomy. However, due to their limited knowledge of astronomy for the managers of the prayer rooms of these supermarkets, they made the method of using the Qibla direction application on their smartphone as a benchmark for how they determine the Qibla direction in the prayer rooms of these supermarkets. The researcher will list the position of the Qibla direction for the prayer room supermarket in the Cirebon City area researched. It will be explained below based on the respective supermarkets mentioned above, as follows:

${ }^{17}$ Sugiyono. Metode Penelitian Kuantitatif, Kualitatif dan R\&D. (Bandung: Alfabeta. 2018.), p. 247-253 


\section{Cirebon Superblock Mall}

The prayer room at Cirebon Superblock Mall is located on the ground floor of this mall building. This prayer room is jampacked, being used by visitors or employees of Cirebon Superblock Mall, especially Muslim ones, to pray while in the mall. Therefore, this musala building is vital or quite crucial for Cirebon Superblock Mall. With a prayer area that is quite large for the class of a supermarket musala, plus it is supported by adequate facilities and makes it comfortable for the congregation who want to pray there. Examples of facilities that can be felt for the assembly, namely::

a. There is a lot of footwear storage space to accommodate the congregation's footwear who wants to put it there.

b. A place for storing goods is guarded by the manager of the Cirebon Superblock Mall. This place of care is handy for people like congregation who want to pray but feel complicated about carrying much shopping without worrying about putting their belongings where.

c. Clean and well-maintained ablution place

d. Prayer equipment such as gloves and mukenah are clean and fragrant to comfort the congregation who want to pray but does not bring prayer equipment.

e. The prayer area is quite spacious, clean, and fragrant. Plus, the room is air-conditioned, so it doesn't make the congregation who pray to stifle.

Researchers are interested in the Cirebon Superblock Mall prayer room to study the measurement of the Qibla direction. Therefore, in January, the researcher applied for a permit for the research place in the prayer room to the Cirebon Superblock Mall management. However, the researcher has not received a confirmation reply on whether to give permission or consent to the researcher.

\section{Grage Mall}

The prayer room at Grage Mall is located on the 4th floor. The prayer room building is located at the very top of the Grage Mall. The Grage Mall prayer room building is directly opposite the topmost car park with a sky roof. Therefore, this musala building, besides its primary purpose for prayer, from here we can also see the city of Cirebon from a height. And because this musala building has an open side, it is beneficial for air circulation in the prayer area itself. So that the congregation who want to pray here feels comfortable because they can feel the calm wind blowing.

When the researchers researched Musala Grage Mall as a research place, the researcher conducted interviews with Mr. Arif Hermawan. The latter worked as an employee of the Grage Group management and at the same time as the manager of the Grage Mall Musala. Mr. Arif stated that for Musala Grage Mall itself, there is no structured management such as the chairman of DKM. The prayer room here is managed directly by the administration of Grage Mall. However, for the care at any time, it is cared for by employee volunteers who use this prayer room to carry out daily prayers.

Information obtained from Mr. Arif Hermawan as the Grage Mall Musala, the prayer room currently in use, was established on November 26, 2017. The prayer room used has been allocated from the prayer room, which was previously located on the ground floor. As for the prayer room, which was once on the ground floor, was built simultaneously as the Grage Mall was built. However, due to the development of Grage Mall, many Grage Mall visitors use the prayer room at every prayer time. The capacity of 
the prayer room can no longer accommodate the number of worshipers who want to pray there because the prayer area is narrow, and the ability of the previous prayer room is inadequate, such as limited ablution places, the absence of good air ventilation, and the lack of a bathroom. Therefore, the last room prayer was allocated to the 4th floor, with the current building quite comfortable for use by pilgrims. Now, this newest prayer room is quite busy being used by the congregation. Not only as a place to perform the fardhu prayer five times. However, as a place for other religious activities, such as Grage Mall internal celebrations and recitations. But for the study itself has been temporarily closed since the pandemic.

Regarding whether the Grage Mall prayer room has been measured for the Qibla direction and what method, I got two different answers from the two people who were the managers of the prayer room. Before I interviewed Mr. Arif Hermawan, I had a little chat with Mr. Saliman, a Grage Mall prayer room manager. I asked about the Grage Mall prayer room, especially regarding the Qibla direction in the prayer room. His answer for the Qibla direction built above here has not been correctly measuring the Qibla direction. He only used the approximate Qibla direction from the previous prayer room below. However, this answer is different from Mr. Arif Hermawan; according to him, for the Qibla direction in the new prayer room, the Qibla direction measurement was carried out in 2017 before this prayer room inaugurated. According to him, the Qibla direction here has been measured by someone from the Ministry of Religion, but Mr. Arif Hermawan himself forgot his name. As for the method used by this person in measuring the Qibla direction in this prayer room, Mr. Arif Hermawan himself forgot to use what kind of tool. And for the certification of measurement at that time from the Ministry of Religion as authentic evidence that the musala has been measured for its Qibla direction by the Ministry of Religion, the certificate itself has not been taken until now.

$$
\text { Data of Grage Mall's Musala: }
$$

Descriptions:

$\varphi \mathrm{m}$ : Makkah Latitude

$\lambda \mathrm{t}$ : Makkah longitude

$\varphi \mathrm{t}$ : Place Latitude

$\lambda \mathrm{t}$ : Place longitude

C : Longitude Difference

$\varphi \mathrm{m}: 21^{\circ} 25^{\prime} \mathrm{NL}$

$\lambda \mathrm{t}: 39^{\circ} 49^{\prime}$ ELong

$\varphi \mathrm{t} \quad: 6^{\circ} 42^{\prime} 47^{\prime \prime} \mathrm{SL}$

$\lambda \mathrm{t}: 108^{\circ} 33^{\prime} 10^{\prime \prime}$ ELong

C : $68^{\circ} 44^{\prime} 10^{\prime \prime}$

Formula:

Shift $\tan \left(1:\left(\tan 21^{\circ} 25^{\prime} \times \cos 6^{\circ} 42^{\prime} 47^{\prime \prime} \div \sin 68^{\circ} 44^{\prime} 10^{\prime \prime}\right.\right.$ $\left.-\sin 6^{\circ} 42^{\prime} 47^{\prime \prime} \div \tan 68^{\circ} 44^{\prime} 10^{\prime \prime}\right)$ )

$=65^{\circ} 7^{\prime} 57,72^{\prime \prime}$

Azimuth $=360^{\circ}-65^{\circ} 7^{\prime}, 72^{\prime \prime}$

$=\underline{294^{\circ} 52^{\prime} 2,28^{\prime \prime}}$

\section{Asia Toserba}

Asia Toserba does not know this supermarket for the people of Cirebon 3 area, especially for the city of Cirebon itself. When they heard his name, most people said that the prices of essential ingredients would be low. Therefore, Asia Department Store is crowded with people who will shop for introductory materials for home appliances; not even a few people are shopping here with a sufficient amount of groceries to be resold as stock in their respective home stalls. Asia, This department store at the end of Ramadan is usually one of the supermarkets visited by many visitors. Visitors flocked to this supermarket at the end 
of the month of Ramadan, namely stocking up on food ingredients, snacks, and drinks to stock up on Eid al-Fitr.

This department store also has a prayer room intended for the public in Asia. The prayer room is also quite busy used by visitors or employees themselves. Musala Asia Toserba is located in the vehicle parking area, to be precise, next to the motorized vehicle parking area. Because of its location near the parking area, this prayer room is widely used by visitors who have just arrived at the Asia Department Store or want to go home but have entered prayer time. Moreover, the Asia Toserba prayer room is quite comfortable for the congregation who prays there because it has adequate facilities, such as good ablution places and air-conditioned prayer rooms, clean and fragrant. Therefore, the community is not reluctant to carry out their prayers there.

In conducting his research in the Asia Toserba prayer room, the Asia Department store management directed the researcher to face someone entrusted by the Asia Toserba management to manage the prayer room. Praise and gratitude can be warmly welcomed by the Asia Toserba musala named Mr. Yuhadi. Mr. Yuhadi himself here, apart from being in charge of the Asia Toserba prayer room, also serves as the security head of Asia Toserba. He takes care of the Asia Toserba prayer room with Mr. Hasan; Mr. Hasan owns a shop in the Asia Toserba parking area. Because Pak Hasan diligently prays in the prayer room there, he helps take care of the Asia Toserba prayer room with Pak Yuhadi, entrusted by the supermarket management. So, on a dayto-day basis, it is Mr. Yuhadi who takes care of the prayer room and is assisted by Mr. Hasan. Due to the management of the prayer room, there is no management structure like DKM.

According to information obtained from $\mathrm{Mr}$.
Yuhadi, the prayer room for Asia Toserba used now is a new renovation in 2014. The prayer room was previously located near the elevator of Asia Toserba's Asri hotel. The prayer room was built since the Asia Department Store was built. However, over time the prayer room was not sufficient for visitors to the Asia Department Store, which was quite crowded. Therefore, Asia Toserba allocated the former prayer room to its current location in 2014. According to Mr. Yuhadi, Asia Toserba's prayer room has become an essential part of the Asia Toserba supermarket. Even though the existing prayer room is a new rehaban, there are often many congregants. Ah, which exploded especially at the time of maghrib in Ramadan, was still not accommodated in the prayer room. Because the prayer space is still limited, so the congregation who will pray, please queue long enough to take turns carrying out their prayers. Even so, Mr. Yuhadi still feels grateful and grateful to the owner of Asia Toserba, who has cared about Asia Toserba's prayer room facilities. For example, this prayer room used a fan in the past; now, it uses AC. When there is paint peeling off and dull, they are immediately repainted. Prayer utensils such as sarongs and mukenah must be washed every three days, and there are still many maintenances that the owner of Asia Toserba pays attention to. This proves that excellent tolerance exists in Asia Department stores, even though Asian owners have nonMuslim beliefs but care about Muslim places of worship.

Next, I asked about the Asia Toserba prayer room direction Mr. Yuhadi. Did the Asia Toserba prayer room measure its path or not? The answer from Mr. Yuhadi was that the direction of the Asia Toserba prayer room was initially straight west following the building. However, over time, there were complaints from several employees of Asia Toserba who often prayed in the musala about the 
direction of the Qibla. From there, they took the initiative to measure the Qibla direction in the prayer room. The measurement of the Qibla direction in the prayer room was carried out in 2016. However, when calculating the Qibla direction, Mr. Yuhadi did not intervene or witness the measurement of the Qibla direction of the prayer room. Because at that time, he was on duty at the top. Therefore, he only knows the reports from his friends but does not know what method to use in the measurement. Additional information obtained from Mr. Hasan, who helped take care of the prayer room with Mr. Yuhadi, said that the prayer room was measured by friends who felt religious. Pak Hasan recalled the measurements themselves using an application on a smartphone. So, the bulk of the Qibla direction carried out in 2016 using the smartphone application is still being used until researchers conduct interviews.

Data of Asia Toserba's Musala:

\section{Descriptions:}

$\varphi$ m: Makkah Latitude

$\lambda \mathrm{t}$ : Makkah longitude

$\varphi \mathrm{t}$ : Place Latitude

$\lambda \mathrm{t}$ : Place longitude

C : Longitude Difference

$\varphi \mathrm{m}: 21^{\circ} 25^{\prime} \mathrm{NL}$

$\lambda \mathrm{t}: 39^{\circ} 49^{\prime}$ Elong

$\varphi \mathrm{t}: 6^{\circ} 42^{\prime} 52^{\prime \prime} \mathrm{SL}$

$\lambda \mathrm{t}: 108^{\circ} 33^{\prime} 46^{\prime \prime}$ ELong

C : $68^{\circ} 44^{\prime} 46^{\prime \prime}$

Formula:

Shift $\tan \left(1:\left(\tan 21^{\circ} 25^{\prime} \times \cos 6^{\circ} 42^{\prime} 52^{\prime \prime} \div \sin 68^{\circ} 44^{\prime} 46^{\prime \prime}\right.\right.$

$\left.\left.-\sin 6^{\circ} 42^{\prime} 52^{\prime \prime} \div \tan 68^{\circ} 44^{\prime} 46^{\prime \prime}\right)\right)$

$=65^{\circ} 8^{\prime} 5,14^{\prime \prime}$

Azimuth $=360^{\circ}-65^{\circ} 8^{\prime} 5,14^{\prime \prime}$

$=\underline{294^{\circ} 51^{\prime} 54,8^{\prime \prime}}$

\section{Surya Toserba Cirebon City}

Surya Toserba is the last sample of researchers researching measuring the Qibla direction. Surya Toserba is a supermarket that has complete sales of goods; besides, what is famous for Surya Toserba is the mobile phone counters that fill the ground floor. Indeed, Surya Toserba has always been renowned for its cellphone sales counters. Therefore, Surya Toserba is always crowded with visitors from the past until now.

Surya Toserba has a prayer room located in front of the parking entrance of Surya Toserba. The Musala Surya Toserba is intended for the public, especially for Surya Toserba visitors who want to pray. It is located at the front, this prayer room is widely used by visitors who have just arrived or are about to go home when it is time for prayer. This musala building is elongated, where the ablution place from this prayer room is located at the back of the prayer room. Although the prayer room is relatively small, it does not reduce the intention of visitors who want to pray at the prayer room.

When researchers came to Surya Toserba to conduct research, the researchers were directed by the management of Surya Toserba with Mr. Lukman, who was trusted as the parking coordinator, and people whom the administration of Surya Toserba authorized to manage the prayer room of Surya Toserba. In his daily life, Mr. Lukman takes care of Surya Toserba's prayer room with volunteer friends from fellow employees of Surya Toserba or friends who have a counter there who often pray at the prayer room of Surya Toserba. You can call them volunteer friends because, in Surya Toserba's prayer room, there is no binding structure for the management of the prayer room. However, Pak Lukman himself has the authority and responsibility in the prayer room. 
According to information obtained from Mr. Lukman regarding the prayer room of Surya Toserba, the prayer room of Surya Toserba was originally established since Surya was built. However, in 2008 the Surya Toserba prayer room was allocated, which used to be at the back, now at the front near the parking entrance of Surya Toserba. According to Mr. Lukman, the prayer room in the supermarket for Surya Toserba itself is significant. Because after all, we as managers of Surya Toserba have to think about facilitating Muslim Surya Toserba visitors who want to perform their five daily prayers.

For the Qibla direction of the Surya Toserba prayer room itself, the Qibla direction has been measured. However, since the Surya Toserba prayer room construction, it was allocated to the front in 2008. Only measurements were taken in 2018, measured by one of Surya Toserba's employees, who often prays as an imam in the prayer room. He felt that the previous Qibla direction at the Surya Toserba prayer room was wrong. Therefore, he invited his friends who often pray in the prayer room to measure the Qibla direction of the Surya Toserba prayer room together, one of which is Mr. Lukman. The method used by the employee in measuring his Qibla direction is to use the Qibla direction application on a smartphone. The exact name of the application, Mr. Lukman himself does not know.

In his interview, Mr. Lukman told researchers that Surya Toserba started in 2019 now has two prayer rooms that he manages. One prayer room in the previous section, the second is the prayer room behind the Surya Toserba building. The prayer room is the AlKhaer prayer room, included in the RW. 03 East Pagongan.

Information obtained from Mr. Lukman, that the Al-Khaer prayer room used to be a public prayer room owned by residents. However, over time, the land around Surya Toserba was purchased by Surya Toshiba, there were no more houses around the prayer room. Seeing that the prayer room was abandoned and there were no worshipers in the prayer room. Surya Toserba took a stand to renovate and manage the prayer room. Until in the end, at this time Mr. Lukman and his volunteer friends prospered the AlKhaer prayer room. From the start, always maintain the cleanliness of the Al-Khaer prayer room, carry out obligatory prayers there, and carry out taraweh prayers in the prayer room. Currently, Mr. Lukman and his friends often pray at the Al-Khaer prayer room than in the prayer room at the front. Maybe because the Al-Khaer prayer room has more adequate facilities than the front prayer room, especially the prayer room at the AlKhaer prayer room can accommodate more jam'ah than the prayer room in front of the Surya Toserba. Therefore, Mr. Lukman and his friends now pray more often at the AlKhaer prayer room.

Regarding the Qibla direction in the AlKhaer prayer room, the Qibla direction in the Al-Khaer prayer room has been carried out since this prayer room was used in 2019. In measuring the Qibla direction of the al-Khaer prayer room, it was carried out by one of the cellphone counter owners at Surya Toserba who was trusted by friends his friend has more religious knowledge than the others, so he can be charged to measure the Qibla direction at the Al-Khaer prayer room. When calculating the Qibla direction in the prayer room, one of Mr. Lukman's friends used the measurement method from the Qibla direction application on his smartphone. 
Data Surya Toserba Cirebon City's Musala: Data of Al-Khaer's Musala:

Descriptions:

$\varphi$ m: Makkah Latitude

$\lambda \mathrm{t}$ : Makkah longitude

$\varphi \mathrm{t}$ : Place Latitude

$\lambda t$ : Place longitude

C : Longitude Difference

$\varphi \mathrm{m}: 21^{\circ} 25^{\prime} \mathrm{NL}$

$\lambda \mathrm{t}: 39^{\circ} 49^{\prime}$ ELong

$\varphi \mathrm{t}: 6^{\circ} 42^{\prime} 51^{\prime \prime} \mathrm{SL}$

$\lambda \mathrm{t}: 108^{\circ} 33^{\prime} 44^{\prime \prime}$ Elong

C : $68^{\circ} 44^{\prime} 44^{\prime \prime}$

Formula:

Shift $\tan \left(1:\left(\tan 21^{\circ} 25^{\prime} \times \cos 6^{\circ} 42^{\prime} 51^{\prime \prime} \div \sin 68^{\circ} 44^{\prime} 44^{\prime \prime}\right.\right.$

$\left.\left.-\sin 6^{\circ} 42^{\prime} 51^{\prime \prime} \div \tan 68^{\circ} 44^{\prime} 44^{\prime \prime}\right)\right)$

$=65^{\circ} 8^{\prime} 4,93^{\prime \prime}$

Azimuth $=360^{\circ}-65^{\circ} 8^{\prime} 4,93^{\prime \prime}$

$=\underline{294^{\circ}} 5^{\prime} 55^{\prime \prime}$
Descriptions:

$\varphi$ m: Makkah Latitude

$\lambda \mathrm{t}$ : Makkah longitude

$\varphi \mathrm{t}$ : Place Latitude

$\lambda \mathrm{t}$ : Place longitude

C : Longitude Difference

$\varphi \mathrm{m}: 21^{\circ} 25^{\prime} \mathrm{NL}$

$\lambda \mathrm{t}: 39^{\circ} 49^{\prime}$ Elong

$\varphi \mathrm{t}: 6^{\circ} 42^{\prime} 50^{\prime \prime} \mathrm{SL}$

$\lambda \mathrm{t}: 108^{\circ} 33^{\prime} 47^{\prime \prime}$ Elong

C : $68^{\circ} 44^{\prime} 47^{\prime \prime}$

Formula:

Shift $\tan \left(1:\left(\tan 21^{\circ} 25^{\prime} \times \cos 6^{\circ} 42^{\prime} 50^{\prime \prime} \div \sin 68^{\circ} 44^{\prime} 47^{\prime \prime}\right.\right.$ $\left.-\sin 6^{\circ} 42^{\prime} 50^{\prime \prime} \div \tan 68^{\circ} 44^{\prime} 47^{\prime \prime}\right)$ )

$=65^{\circ} 8^{\prime} 5,94^{\prime \prime}(\mathrm{B}-\mathrm{U})$

Azimuth $=360^{\circ}-65^{\circ} 8^{\prime} 5,94^{\prime \prime}$

$=\underline{\mathbf{2 9 4}}^{\circ} \mathbf{5 1}^{\prime} \mathbf{5 4 ^ { \prime \prime }}$

Recapitulation of Qibla Direction for Supermarket Musala in Cirebon City

\begin{tabular}{|c|c|c|c|c|c|}
\hline No & Musala Names & Musala Profiles & Calibration Means & Calibration Results & Descriptions \\
\hline 1 & $\begin{array}{l}\text { Musala Cirebon } \\
\text { Superblock } \\
\text { Mall }\end{array}$ & $\begin{array}{l}\text { Address: Jl. Dr. } \\
\text { CiptoMangunkusumo } \\
\text { No. } 2 \text { Kel.Pekiringan, Kec. } \\
\text { Kesambi, Kota Cirebon, } \\
\text { Jawa } \\
\text { Barat } 45131 \\
\text { administrators: - } \\
\text { Estabelishment: - }\end{array}$ & $\begin{array}{l}\text { Qibla measuring } \\
\text { tool (then): - } \\
\text { Qibla measuring } \\
\text { tool (now): - }\end{array}$ & $\begin{array}{l}\text { Qibla azimuth (then): } \\
\text { - } \\
\text { Qibla azimuth (now): - }\end{array}$ & $\begin{array}{l}\text { Not willing to } \\
\text { be examined }\end{array}$ \\
\hline 2 & $\begin{array}{l}\text { Musala Grage } \\
\text { Mall }\end{array}$ & $\begin{array}{l}\text { Address: Jl. Tentara Pelajar } \\
\text { No. } 1 \text { Kel. Kejaksan } \\
\text { Kec.Kejaksan, Kota } \\
\text { Cirebon, Jawa Barat } 45123 \\
\text { Administrators: Arif } \\
\text { Hermawan } \\
\text { Estabelishment: } 26 \\
\text { November } 2017\end{array}$ & $\begin{array}{l}\text { Qibla measuring } \\
\text { tool (then): } \\
\text { Compass Qibla } \\
\text { measuring tool } \\
\text { (now): Suunto } \\
\text { Compass }\end{array}$ & $\begin{array}{l}\text { Qibla azimuth (then) } \\
: 284^{\circ} \\
\text { Qibla azimuth (now): } \\
294^{\circ} 52^{\prime} 2,28^{\prime \prime}\end{array}$ & $\begin{array}{l}\text { Qibla direction } \\
\text { deviated to } \\
\text { the left by } \\
10^{\circ} 52^{\prime} 2,28^{\prime \prime}\end{array}$ \\
\hline 3 & $\begin{array}{l}\text { Musala Asia } \\
\text { Toserba }\end{array}$ & $\begin{array}{l}\text { Address: Jl. Karangggetas } \\
\text { No. 25-27 Kel. Panjunan } \\
\text { Kec. Lemahwungkuk Kota } \\
\text { Cirebon, Jawa Barat } 45112 \\
\text { Administrators: Yuhadi } \\
\text { Establishment: } 2014\end{array}$ & $\begin{array}{l}\text { Qibla measuring } \\
\text { tool (then): } \\
\text { Smartphone } \\
\text { Applications } \\
\text { Qibla measuring } \\
\text { tool (now): Suunto } \\
\text { Compass }\end{array}$ & $\begin{array}{l}\text { Qibla azimuth (then) } \\
\text { : } 289 \\
\text { Qibla azimuth (now): } \\
294^{\circ} 51^{\prime} 54,8^{\prime \prime}\end{array}$ & $\begin{array}{l}\text { Previous qibla } \\
\text { direction } \\
\text { deviated to } \\
\text { the left by } 5^{\circ} \\
51^{\prime} 54,8^{\prime \prime}\end{array}$ \\
\hline
\end{tabular}




\begin{tabular}{|c|c|c|c|c|c|}
\hline No & Musala Names & Musala Profiles & Calibration Means & Calibration Results & Descriptions \\
\hline 4 & $\begin{array}{l}\text { Musala Surya } \\
\text { Toserba Kota } \\
\text { Cirebon }\end{array}$ & $\begin{array}{l}\text { Address: Jl. Karanggetas } \\
\text { No. } 23 \text { Kel. Panjunan } \\
\text { Kec. Lemahwungkuk, Kota } \\
\text { Cirebon, Jawa Barat } 45112 \\
\text { Administrators: Lukman } \\
\text { Estabelishment: } 2008\end{array}$ & $\begin{array}{l}\text { Qibla measuring } \\
\text { tool (then): } \\
\text { Smartphone } \\
\text { Applications } \\
\text { Qibla measuring } \\
\text { tool (now): Suunto } \\
\text { Compass }\end{array}$ & $\begin{array}{l}\text { Qibla azimuth (then) } \\
: 300 \\
\text { Qibla azimuth (now): } \\
294^{\circ} 51^{\prime} 55^{\prime \prime}\end{array}$ & $\begin{array}{l}\text { Previous qibla } \\
\text { direction } \\
\text { deviated to } \\
\text { the right by } 5^{\circ} \\
8^{\prime} 50^{\prime \prime}\end{array}$ \\
\hline 5 & $\begin{array}{l}\text { Musala Al- } \\
\text { Khaer }\end{array}$ & $\begin{array}{l}\text { Address: RW. } 03 \text { Pagongan } \\
\text { Timur Kel. Panjunan } \\
\text { Kec. Lemahwungkuk, Kota } \\
\text { Cirebon, Jawa Barat } 45112 \\
\text { Administrators:. Lukman } \\
\text { Estabelishment: } 2019\end{array}$ & $\begin{array}{l}\text { Qibla measuring } \\
\text { tool (then): } \\
\text { Smartphone } \\
\text { Applications } \\
\text { Qibla measuring } \\
\text { tool (now): Suunto } \\
\text { Compass }\end{array}$ & $\begin{array}{l}\text { Qibla azimuth (then) } \\
: 280 \\
\text { Qibla azimuth (now): } \\
294^{\circ} 51^{\prime} 54^{\prime \prime}\end{array}$ & $\begin{array}{l}\text { Previous qibla } \\
\text { direction } \\
\text { deviated to } \\
\text { the left by } 14^{\circ} \\
51^{\prime} 54,8^{\prime \prime}\end{array}$ \\
\hline
\end{tabular}

The Method Used in Determining the Qibla Direction of the Supermarket Musala in Cirebon City

Previously it was explained that to obtain the virtue of facing the Qiblah in prayer; it is required to try as much as possible to get results that can approach the truth in determining the Qibla direction of a mosque or prayer room. So, to achieve this truth, several Islamic leaders learn from experience or knowledge about how to choose the Qibla direction in their area.

In general, in determining the Qibla direction of the supermarket prayer room, which has been carried out so far in each of the supermarkets that the researchers conducted research, there are two methods used by the manager of the prayer room, namely:

\section{Qibla Direction App on Smartphone}

As we know nowadays, almost everyone has a smartphone. It is undeniable that smartphones are not only to facilitate human affairs in work. However, now on smartphones, Islamic-based applications make it easier for us to worship; one example is finding the Qibla direction. Therefore, some of the managers of the supermarket prayer room in determining the Qibla direction at the supermarket prayer room, the application of the Qibla direction on a smartphone is the most widely used method, such as measurement at the Asia Musala, the Department Store, Panjunan Village, Lemawungkuk Sub-district, Surya Toserba Musala, Panjunan Sub-District, Lemawungkuk Sub-District and Al Musala Al. -Khaer RW.03 Pagongan Timur Lemawungkuk District, Cirebon City. Besides that, another convenience is using the Qibla direction application on a smartphone in determining the Qibla direction, which everyone can use. Because using this application to determine the Qibla direction, there is no need to deepen astronomy but only with quotas and signals. Therefore, if the percentage on the smartphone runs out, it cannot be accessed to determine the Qibla direction. If there is a lack of signal or signal in that place, then the application is disrupted in its use, it can be inaccurate. Even the application can not be used. So if you want to use the Qibla direction application on a smartphone, it is necessary to pay attention to the signal conditions, the influence of magnets and objects that contain magnets, and the iron content around the smartphone because it can affect its accuracy. ${ }^{18}$

\footnotetext{
18 Gunawan \& Nur Aisyah, S.H.I, M.H.I, Akurasi Kompas Digital Pada Smartphone Android Dalam Penentuan
} 


\section{Magnetic Compass}

A compass is a tool that is often used to determine the direction or magnitude of the angle of a flat plane on the earth's surface. As with choosing the Qibla direction in supermarket prayer rooms, primarily using the Qibla direction application on a smartphone, the method of determining the Qibla direction using a magnetic compass is also carried out by Grage Mall. This compass has advantages and disadvantages like other measuring instruments; among the benefits is its relatively low price so that anyone can use it besides its effortless use. Then another advantage of this tool is that it can be used anytime and anywhere. The drawback is that this tool is susceptible to metal bands to shift the compass needle. ${ }^{19}$

\section{Analysis of the Method in Measuring the Qibla Direction at the Supermarket Prayer Room in Cirebon City}

To gain confidence and stability in our prayers without a doubt in our hearts, we need to make every effort so that the Qibla direction we use for worship leads to the path we think is right facing the Baitullah. Suppose we have found this direction based on the results of astronomy science that we have studied, for example. So, we must use the Qibla direction measured using knowledge.

So, of course, we need to conclude which direction is closest to the truth in the actual Qibla direction. Thus, responding to the many differences in the magnitudes of the Qibla direction angles in the community so far, it is necessary to re-check by measuring the Qibla direction again. There should be many methods of determining the Qibla

\footnotetext{
Arah Kiblat, (Jurnal Hisabuna, vol 2, No 2, Juni 2021), p. 26

19 Saitul Mahter \& Muhammad Saleh Ridwan, Dinamika penentuan Arah Kiblat Menggunakan alat klasik dan modern Di Masjid Sultan Alauddin Madani, (Jurnal Hisabuna, Vol 1 No 1 Januari 2021), p. 7
}

direction that can be categorized as accurate, such as deciding the Qibla azimuth through calculations with scientific calculators, using advanced technology tools such as theodolite and GPS (Global Position System), even in the traditional way, namely seeing the shadows of the sun at certain times. rashdul Qibla) after knowing the latitude and longitude data of the place and knowing the Latitude and longitude of the Kaaba.

Measuring the Qibla direction is very influential on our specificity in worship and when determining the location of the Musala construction. Even though the Ministry of Religion currently publishes a Qibla compass and calculations for several areas, it would be nice to know how and how to determine the actual Qibla direction.

As it is known that the reality is, the Qibla direction of the supermarket prayer room buildings in the Cirebon City area is diverse, meaning that most of the supermarket prayer room Qibla directions are not following the proper Qibla direction, where for the Cirebon City area, the Qibla azimuth value is 294. Here the researcher will analyze the position of the Qibla direction of the supermarket prayer room in the city of Cirebon by taking five samples of the supermarket prayer room which the researchers will analyze, as follows:

1. Musala of Cirebon Superblock Mall

Researchers do not yet know azimuth Qibla Musala Cirebon Superblock Mall. Because until now, researchers have not received clear news for research permits in the prayer room.

2. Musala of Grage Mall

Azimuth Qibla Musala Grage Mall used to be 284 . Meanwhile, when the researchers measured the Qibla direction in the prayer room, the researchers got the Qibla azimuth of 29452 ' 2.28”. It means that the slope 
or deviation of the Qibla direction of the Grage Mall prayer room has a shortage of -1052 ' 2.28".

\section{Musala of Asia Toserba}

Azimuth Qibla Musala Asia Department store used to be 289. However, when the researchers measured the Qibla direction in the prayer room, the researchers got the Qibla azimuth of 294 51' 54.8”. It means that the slope or deviation of the Qibla direction of the Asia Department Store is experiencing a shortage of -5 51' 54.8”.

4. Musala of Surya Toserba Kota Cirebon

Azimuth Qibla Musala Surya Toserba Cirebon City used to be 300 . Meanwhile, when the researchers measured the Qibla direction in the prayer room, the researchers got the Qibla azimuth of 294 51' 55”. This means that the slope or deviation of the Qibla direction of the Surya Toserba Cirebon City prayer room has an excess of 5 8' 5 ".

5. Musala of Al-Khaer

Azimuth Qibla Musala Surya Toserba Cirebon City used to be 280 . Meanwhile, when the researchers measured the Qibla direction in the prayer room, the researchers got the Qibla azimuth of 294 51' 55.3". It means that the slope or deviation of the Qibla direction of the Al-Khaer prayer room has a deficiency of -14 51 '55.3".

The results of the calculation on the measurement of the Qibla direction from the four samples of the supermarket prayer room as the place of this research, it turned out that all of them were found to have an inaccurate Qibla direction. There is still a difference between the Qibla direction of the prayer room first and the Qibla direction calculated by the researcher. The distinction itself ranges from 5 to 14 . This means that in determining the direction of Qibla in supermarket prayer rooms, there are still many mistakes in deciding it. When viewed from a long-term perspective of fiqh, there will be differences of opinion among the opinions of the priests of the schools of thought. The contrast of 5 to 14 is considered to be far off, according to Imam Syafii. However, according to Imam Hanafi, it is still included in the Jihat Sughro and is still included in tolerance limits. ${ }^{20}$

As for the differences in the direction of the supermarket musala qibla in the Cirebon City area, which is the research study of researchers, several factors cause this to happen. Among them, namely from the tools used to measure (instrument error), and it could also be from the characteristic of the person himself who experienced errors in measurement (human error). The Qibla direction that is not right in the supermarket prayer rooms in the city of Cirebon is due to a lack of understanding of the science of calculating the Qibla direction according to the provisions of astronomy by the administrators of the supermarket prayer room. This factor causes other factors, such as the tools used in Qibla direction measurement that does not match the standardization of Qibla direction measurement according to astronomy.

From the analysis above, it can be illustrated that a prayer room supermarket in the Cirebon City area, in general, is not following the Qibla direction due to calculations pursuing astronomy. Astrology is undoubtedly positive to increase confidence or stability without the slightest doubt in the heart.

However, the researchers appreciate the efforts of the figures or prayer room administrators who are responsible for managing the prayer room who have contributed energy and thoughts in an attempt to determine the direction of the supermarket prayer room in the Cirebon City area, so that mall visitors

20 Siti Nurul Iffah Faridah, Toleransi Arah Kiblat Menurut Mazhab Hanafi Dalam Persfektif Fikih Dan Astronomi, (Tesis UIN Walisongo Semarang,2020), p. 98 
or worshipers who want to pray in the prayer room can comfortably perform their prayers.

\section{Conclusions}

Based on the results of the analysis that has been done by researchers regarding the measurement of the Qibla direction of the supermarket in the city of Cirebon. Researchers observed and re-examined the overall thesis analysis. In the end, researchers can conclude things as follows:

1. Of the four samples of the supermarket prayer room which became the object of research, all of them had measured the Qibla direction. One prayer room, namely the Grage Mall prayer room, whose method and measurement of the Qibla direction claims to have been calculated using a Qibla compass. As for the other three prayer rooms, namely the Asia Toserba prayer room, the Surya Toserba prayer room in Cirebon City, and the Al-Khaer prayer room, measure the Qibla direction not use the appropriate method in astronomy, namely utilizing the Qibla direction application on their smartphone. Of course, using the Qibla direction application on a smartphone is inaccurate. This method's method is partly an error in determining the Qibla direction. Due to his ignorance of astronomy in measuring the Qibla direction and ignorance of the magnitude of the Qibla direction angle in the Cirebon City area resulted in the direction of the Qibla musala supermarket in the Cirebon City area experiencing a wrong Qibla direction.

2. The direction of the musala supermarket in the Cirebon City area is varied. After the researchers made observations using the Suunto compass, the researchers got the results from the four supermarket prayer rooms that were the research samples. Of the four examples of the prayer room, there is a deviation (difference) between the Qibla direction of the first prayer room and the Qibla direction calculated and measured by researchers. As for the difference in slope or deviation from the four samples of prayer rooms, namely the Grage Mall prayer room, there is a difference of $-1052 ' 2.28$ ", the Asia Toserba prayer room has a difference of -5 51'54.8", Surya Toserba prayer room has a difference of 5 " 5". The Al-Khaer prayer room there is a difference of $-1451^{\prime} 55.3$ ”. This is most likely influenced by the method used in determining the Qibla direction.

\section{References}

Asia Toserba. Profile Asia Toserba Cirebon, Kota Cirebon: Manajemen Asia Toserba Cirebon, t.th.

Azhari, Susiknan. Ensikopledi Hisab Rukyat, edisi revisi. Yogyakarta: Pustaka Pelajar, 2008, Cet. ke-2,

Badan Hisab dan Rukyat Departemen Agama. AL-Manak Hisab Rukyat, Jakarta: Proyek Pembinaan Badan Peradilan Agam Islam, 1981.

Badan Pusat Statistik. Kota Cirebon Dalam Angka, Kota Cirebon, 2015

Budiwati, Anisah \& Saiful Aziz. "Akurasi Arah kiblat Masjid Di Ruang Publik", Jurnal Sains Sosial dan Humaniora, Vol. 2, No. 1, Maret 2018.

Dahlan, Abdul Azis. Ensiklopedi Hukum Islam, Jakarta: PT Ichtiar Baroe Van Hoeve, 1996, Cet.ke-1.

Departemen Agama.Pedoman Penentuan Arah Kiblat. Jakarta: Dirjen Binbaga Islam

Dirbinpera, 1996

Departemen P \& K. Kamus Besar Bahasa Indonesia, Jakarta: Balai Pustaka. 1989, Cet. ke-2.

Arifin, Nurul. "Integrasi Teks-Teks Syar'i Yang Terkait Dengan Arah Kiblat Dalam Konteks Astronomi”, Jurnal El-Falaky, Vol. 4, No. 1, 2020.

Faiz, Abd. Karim. "Moderasi fiqh Penentuan 
Arah Kiblat: Akurasi yang Fleksibel”, Journal of Islamic Law,Vol. 1, No 1, 2020.

Faridah. Siti Nurul Iffah. Toleransi Arah Kiblat

Menurut Mazhab Hanafi Dalam Persfektif

Fikih Dan Astronomi, Tesis UIN Walisongo

Semarang, 2020.

Grage Group.Profile Grage Mall. Kota Cirebon:

Manajemen Grage Mall, t.th.

Gunawan \& Nur Aisyah. "Akurasi Kompas

Digital Pada Smartphone Android Dalam

Penentuan Arah Kiblat", Jurnal Hisabuna,

Vol. 2, No 2, Juni 2021.

Hambali, Slamet. Ilmu Falak 1: Penentuan Awal

Waktu Shalat Dan Arah Kiblat Seluruh

Dunia, Semarang: PPS IAIN Walisongo,

2011, Cet. ke-1.

Hambali, Slamet. Ilmu Falak: Arah Kiblat Setiap

Saat, Yogyakarta: Pustaka Ilmu,

Hendri \& Zul Efendi. "Problematika Ilmu Falak Kontemporer: Studi Kiblat Di Rumah Makan Pinggir Jalan Lintas Kabupaten/ Kota Se Sumatera Barat", Jurnal AlMarshad: Jurnal Astronomi Islam dan IlmuIlmu Berkaitan, Vol. 7, No. 1, Juni 2021.

Hosen \& Eka Nurhalisa. "Akurasi Arah Kiblat

Pemakaman Desa Ponteh Kecamatan Galis Kabupaten Sumenep", Jurnal Al-Marshad: Jurnal Astronomi Islam dan Ilmu-Ilmu Berkaitan, Vol. 5, No. 2, 2019.

Ishaq, H. Metode Penelitian Hukum Dan Penelitian Skripsi, Tesis, Serta Disertasi. Bandung: ALFABETA, 2017.

Izzuddin, Ahmad. Ilmu Falak Praktis. Semarang: Pustaka Rizki Putera, 2012.

Izzuddin, Ahmad. Menentukan Arah Kiblat Praktis, Semarang: Walisongo Press, 2010, Cet. ke-1.

Jamil, Abdul. Ilmu Falak Menurut Teori dan Aplikasi. Jakarta: Amzah, 2016, Cet. ke-4.

Jaya, Dwi Putra. "Dinamika Penentuan Arah Kiblat", Jurnal Ilmiah Mizani, Vol. 4, No. 1,2017

Kadir, A.Fiqih Kiblat. Yogyakarta: Pustaka Pesantren, 2012.

Kamus Besar Bahasa Indonesia Pusat Bahasa.
Jakarta: PT. Gramedia Pustaka Media, 2008, Cet. ke-4.

Kementerian Agama. Buku Saku Hisab Rukayt. Jakarta: Sub Direktorat Pembinaan Syariah dan Hisab Rukyat, 2013

Khazin, Muhyiddin. Ilmu Falak Dalam Teori Dan Praktik. Jogjakarta: Buana Pustaka

Ma'rufin Sudibyo, Muhammad.Sang Nabi Pun Berputar. Solo: Tinta Medina. 2011

Mahter, Saitul \& Muhammad Saleh Ridwan. "Dinamika Penentuan Arah Kiblat Menggunakan Alat Klasik dan Modern Di Masjid Sultan Alauddin Madani”, Jurnal Hisabuna, Vol. 1, No. 1, Januari 2021.

Muhyidin Khazin, Kamus Ilmu Falak, Yogyakarta: Pustaka Pelajar, 2005.

Nasution, Harun.Ensiklopedi Islam Indonesia, Jakarta: Djambatan, 1992.

Nawawi, Yahya bin Syarf Al. Al Minhaj Syarh Muslim bin Al Hajjaj. Mesir: Dar Ihya'AtTurots, $1392 \mathrm{H}$.

Qurthuby. Al-Jami' Lil Ahkamil Qur'an, Beirut: Dar al-Fikr, t.th., Juz II.

Somawinata,Yusuf. "Penentuan Arah Kiblat dan Toleransi Penyimpangannya”, Jurnal AlAhkam, Vol. 3, No. 2, 2009.

Sugiyono. Metode Penelitian Kuantitatif, Kualitatif dan R\&D, Bandung: Alfabeta.

Surya Lestari Mandiri, Profile Surya Toserba Kota Cirebon, Kota Cirebon: Manajemen Surya Toserba Kota Cirebon, t.th.

Syaiful Mujab, "Kiblat Dalam Persfektif Madzhab-Madzhab Fiqh", Jurnal Yudisia, Vol. 5, No. 2, 2014.

Tirmidzi. Sunan al-Tirmidzi, Juz I. Beirut: Dar al-Fikr. 2003.

Wahidi, Ahmad dan Evi Dahliyatin Nuroini. Arah kiblat dan Pergesaran Lempeng: Perspektif Syar'iyah dan Ilmiyah, Malang: UIN MALIKI Press, 2012.

Yunus, Muhammad, "Hadis Tentang Arah Kiblat: Kritik Pemikiran Ali Mustofa Yaqub”, Jurnal Al-Irfani, Vol. VI, No. 1, 2020.

Zuhaili, Wahbah. al-Figh al-Islami wa Adillatuh, Damaskus: Dar al-Fikr. 1997, Jilid I. 